\title{
EVALUATION OF USING SOME UNTRADITIONAL ENERGY SOURCES IN BROILER CHICKEN DIETS ON PERFORMANCE, CARCASS CHARACTERISTICS AND ECONOMIC EFFICIENCY: 1- CAKE BY- PRODUCT.
}

\author{
A.M.M. Abido' ${ }^{1}$ F.M. Abdel Azzem² ; S.A. Abd El-Fattah $^{2}$; T.M. El-Afifi ${ }^{1}$ and A.I. El- \\ Faham $^{2}$ \\ ${ }^{1}$ Regional Center for Food and Feed, Agriculture Research Center Giza, Egypt \\ ${ }^{2}$ Poultry Production Dept., Fac. Of Agric., Ain Shams Univ., Egypt
}

SUMMARY

\begin{abstract}
A total number of 210 unsexed 7 days old Hubbard broiler chicks were used in this study to assessment of using cake by-products (CBP) as an alternative energy source in broiler diets on growth performance, carcass characteristics and economic efficiency. Chicks were divided randomly into seven equal treatments (30 birds each) contained $0 \%, 15 \%, 30 \%, 45 \%, 60 \%, 75 \%$ and $100 \%$ replacing yellow corn with CBP. Results of this experiment showed that, chicks' performance including live body weight (LBW), daily weight gain (DWG), daily feed consumption (DFC) and feed conversion ratio (FCR) didn't significantly differ between treatments at different periods and overall period. Carcass traits were not significantly affected among treatments. Economic study indicated that $100 \% \mathrm{CBP}$ treatment is the most profitable diet among experimental diets. In conclusion, cake by-products (CBP) can be used with broiler chicks' diets without any negative effect on bird performance, carcass traits and improved the relative economic efficiency.
\end{abstract}

Keywords: Chicks, cake by-products, performance, carcass and economic efficiency.

\section{INTRODUCTION}

Waste product from bakeries had been considered as one of the non-traditional ingredients has been used in the last few years as an alternative energy source to substitute corn in poultry diets. The American Association of Feed Control Officials defined this ingredient under the official name of "dried bakery product" (DBP). The DBP is a mixture of surplus and unsalable materials (bread, cakes, crackers, rolls, cookies, pastries and even unbaked dough) collected from bakeries and other food processors. Moreover, the basic ingredients of bakery products are wheat flour, oil (mostly palm oil), salt, shortening, sugar, yeast, chemical leavening agents and bread improvers (Mousa et al., 1992).

The DBP was also called bakery by- product (BBP). The BBP could replace corn for its relatively lower cost in poultry diet formulation. Further, some of these by-products may be due to fermentation processes thrown in the garbage, resulting in environmental pollution (EI-Yamny et al., 2003; AITulaihan et al., 2004; Ragab et al., 2006 and Afzalzadeh et al., 2007).

Studies conducted on BBP revealed that it could be replaced up to $100 \%$ of corn in broiler chicks diet without any adverse effects on their productive performance, offering economic benefits for both bakery and poultry producers (Al-Ruqaie et al., 2011; Torki and Kimiaee, 2011 and Ayanrinde et al., 2014). Those authors added that, although the beneficiary of BBP as a good alternative source of energy, its high content of salt $(\mathrm{NaCl})$ limits its use in poultry diet formulation. Also, Ayanrinde et al. (2014), Adeyemo et al. (2013), Zand and Foroudi (2011) and Ragab et al. (2006) concluded that, bakery by- products BBP can completely replace corn in broiler diets from day to 35 days of age without adversely affecting on carcass characteristics which included live body weight,carcass weight, edible offal (liver + heart + gizzard).

Moreover, Madiya et al. (2003) concluded that the use of BBP in broiler production resulted in a reduction of feed costs by nearly a third, and consequently had a positive impact on the total cost of production. In a line with these reports, Adeyemo et al. (2013), Al-Ruqaie et al. (2011) and Ragab et al. (2006) showed that costs of feed intake and feed for the production of a $\mathrm{kg}$ live weight of chickens at 35

Issued by the Egyptian Society of Nutrition and Feeds 
days of age were significantly linearly diminished with substitution of either $20,40,60,80$ or $100 \%$ bakery waste product (BWP) instead of corn, when contrasted with those fed the control diet ( $0 \% \mathrm{BWP})$.

The aim of this present study was to assess the dietary inclusion of cake by-products (CBP) as alternative energy sources, on growth performance, carcass characteristics and economic efficiency of broiler chicks.

\section{MATERIALS AND METHODS}

The current study was carried out at the Poultry Nutrition Farm, Poultry Production Department, Faculty of Agriculture, Ain Shams University, Shoubra El-kheima, Qalubia Governorate and laboratories of the Regional Center for Food and Feed, Agriculture Research Center, Giza Governorate, Egypt. Pretreatment of bakery by-product: tested (CBP) was pretreated before adding to experimental diets as follow: A quantity of (CBP) was brought from Edita Company $\left(6^{\text {th }}\right.$ October City, Giza), then spread on an oven for drying at $60 \square$. After complete dryness produced dried (CBP), then grounded in hummer mill to $1.0 \mathrm{~mm}$ in size without any special treatments and stored until formulating experimental diets. Proximate analysis according to (AOAC, 2012) was done on samples of (CBP) table 1.

\section{Birds and management}

Two hundred and ten unsexed day old of Hubbard broiler chicks were obtained from commercial hatchery (EL-ADLIA, Sharkia Governorate), randomly divided into 7 treatments and each treatment comprised of 30 chicks in five replicates of six chicks each. During the first week of age chicks were let for free feeding on the basal control diet of experiment. At seven day old, chicks were randomly allotted on the experimental groups ( 30 chicks each) in a completely randomized design.

All chicks were kept under the same managerial, hygienic and environmental conditions throughout the entire experimental period that lasted for 40 days of age.

\section{The experimental diets}

Diets were formulated in mash form to contain 3025, 3100 and $3200 \mathrm{ME}$ (Kcal/Kg) energy with 23, 21 and $20 \% \mathrm{CP}$ for starter, grower and finisher diets, respectively. In this experiment, the chicks were assigned to seven experimental diets during the period from 7 to 40 days as follows:

T1: Birds were fed corn-soybean diets (C) as control basal diets.

T2-7: Replacing $15,30,45,60,75$, and $100 \%$ corn of the basal diets by (CBP).

\section{Measurements}

\section{Productive Performance and carcass characteristics:}

Live body weight, daily body weight gain, daily feed consumption and feed conversion ratio were determined and recorded from 7 to 40 days of age. At 40 days of age, five live birds from each treatment were randomly chosen and slaughtered after fasting for $12 \mathrm{hrs}$. After sacrificing, internal organs (liver, heart, gizzard, spleen and bursa) were removed and weighed. After the removal of blood, feathers, head, viscera, shanks and edible parts (gizzard, heart and lever) the rest of body was weighted to determine the dressed weight.

\section{Economic Evaluation:}

The economic evaluation of the end product was based on the difference between growth rate and feeding cost. The economic efficiency traits were calculated according to North (1981) in relation to the price of local market.

The composition and calculated analysis of the experimental diets are presented in Table (1): 
Table (1): Composition and calculated analysis of the experimental diets.

\begin{tabular}{|c|c|c|c|c|c|c|}
\hline \multirow{4}{*}{ Ingredients \% } & \multicolumn{6}{|c|}{ Dietary treatments } \\
\hline & \multicolumn{2}{|c|}{ 7-21 days } & \multicolumn{2}{|c|}{$22-35$ days } & \multicolumn{2}{|c|}{ 36-40 days } \\
\hline & Control & $100 \%$ & Control & $100 \%$ & Control & $100 \%$ \\
\hline & $\mathrm{C}$ & CBP & $\mathrm{C}$ & $\mathrm{CBP}$ & $\mathrm{C}$ & CBP \\
\hline Yellow corn $(7.7 \% \mathrm{CP})$ & 50.00 & 0.00 & 55 & 0 & 60 & 0 \\
\hline Soybean meal (44 \% CP) & 38.00 & 38.00 & 30.25 & 31.5 & 25.1 & 26.2 \\
\hline Corn gluten meal $(65.3 \% \mathrm{CP})$ & 3.00 & 3.50 & 4.4 & 4.5 & 6.1 & 6 \\
\hline Cake by-product $(6.25 \mathrm{CP})^{*}$ & 0.00 & 50.00 & 0 & 55 & 0 & 60 \\
\hline Wheat bran $(13.5 \% \mathrm{CP})$ & 0.40 & 3.00 & 1.85 & 3.2 & 0.7 & 2.5 \\
\hline Soybean oil & 4.35 & 1.20 & 4.5 & 1.6 & 4.5 & 1.6 \\
\hline Dicalcium phosphate & 1.94 & 2.08 & 1.7 & 1.98 & 1.6 & 1.73 \\
\hline Limestone & 1.21 & 1.15 & 1.4 & 1.3 & 1.1 & 1.1 \\
\hline Salt ( $\mathrm{Na} \mathrm{cl}$ ) & 0.30 & 0.30 & 0.3 & 0.3 & 0.3 & 0.3 \\
\hline Premix** & 0.30 & 0.30 & 0.3 & 0.3 & 0.3 & 0.3 \\
\hline L-Lysine & 0.20 & 0.22 & 0.1 & 0.12 & 0.15 & 0.15 \\
\hline DL- Methionine & 0.30 & 0.25 & 0.2 & 0.2 & 0.15 & 0.12 \\
\hline Total & 100.00 & 100.00 & 100.00 & 100.00 & 100.00 & 100.00 \\
\hline \multicolumn{7}{|l|}{ Calculated analysis*** } \\
\hline $\mathrm{ME}(\mathrm{Kcal} / \mathrm{Kg})$ & 3029.3 & 2997.3 & 3099.6 & 3105.59 & 3200.9 & 3218.29 \\
\hline $\mathrm{CP} \%$ & 22.99 & 22.95 & 20.91 & 20.93 & 20.01 & 19.78 \\
\hline Calorie/Protein Ratio (C/P) & 131.75 & 130.60 & 148.23 & 148.37 & 159.96 & 162.70 \\
\hline Calcium $\%$ & 1.050 & 1.057 & 1.047 & 1.071 & 0.895 & 0.920 \\
\hline Available phosphorous \% & 0.508 & 0.490 & 0.455 & 0.456 & 0.429 & 0.399 \\
\hline Lysine $\%$ & 1.486 & 1.440 & 1.194 & 1.168 & 1.112 & 1.052 \\
\hline Methionine \% & 0.668 & 0.615 & 0.554 & 0.556 & 0.500 & 0.467 \\
\hline Meth. + Cys. \% & 1.067 & 1.095 & 0.928 & 1.010 & 0.869 & 0.920 \\
\hline \multicolumn{7}{|c|}{ 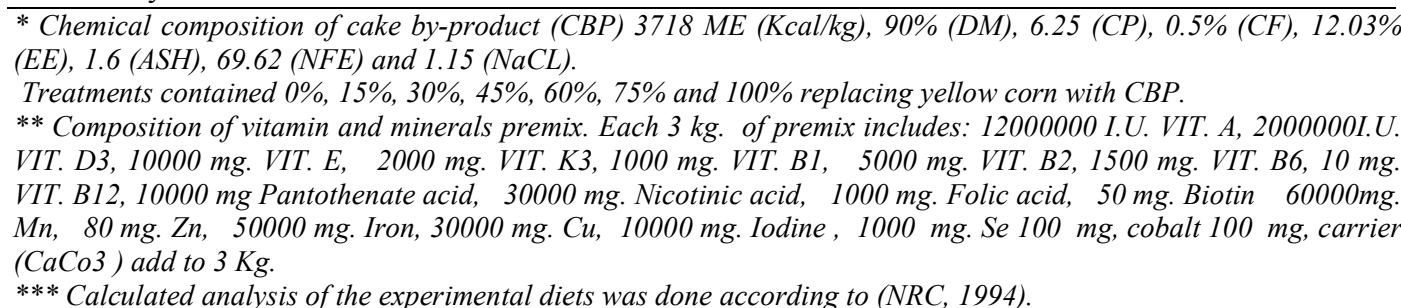 } \\
\hline
\end{tabular}

\section{Statistical analysis:}

Data collected in this study was statistically analyzed using the general linear models (GLM) of SAS, (2005) using one-way analysis of variance. Duncan's Multiple Range Test (Duncan, 1955) was used to separate means when separation was relevant. The following statistical model was applied:

$$
\mathrm{Yij}=\mu+\mathrm{Ti}+\mathrm{eij}
$$

Where:

$$
\begin{aligned}
& Y_{i j}=\text { the } j \text { observation of the } i^{\text {th }} \text { treatment; } \\
& \mu=\text { an effect of overall mean; } \\
& T_{i}=\text { a fixed effect of } i^{\text {th }} \text { feeding treatment; } \\
& \varepsilon_{i j}=\text { a random experimental error assumed NID }\left(0, \sigma \mathrm{e}^{2}\right)
\end{aligned}
$$

\section{RESULTS AND DISCUSSION}

\section{Productive performance of live body weight (LBW) and daily weight gain (DWG):}

The effect of replacing different levels of cake by-products on productive performance are presented in Table (2). The initial live body weights (at 7day-old) were nearly similar that ranged from 139.53 to $140.96 \mathrm{~g}$, which due to the effect of randomize procedure. During the overall period (7-40 d of age), data 
showed that gained nearly the same between all treatments. Also, the values of DWG during the all periods show no significant differences. However, the highest live body weight and daily body weight gain were recorded by birds on treatment $30 \%$ and $45 \%$, CBP respectively could be as a result of the high feed intake and to the lesser crude fiber content in cake by product. The outcome hence recommends that wheat (the significant part of CBP) is thermolabile, in this way supporting the perception by Williams et al. (1997) who reported expanded accessibility of protein, energy and degradation of anti-nutritional factors amid wheat preparing which enhanced the performance of broilers. The higher temperature required in feed preparing may have significantly contributed to the decrease of the detrimental effects associated with non-starch polysaccharides (NSP) contained in the wheat by-products. Heat handling had been accounted for to influence physical qualities of NSPs [Cowieson, (2005) and Gonzalez-Alvardo et al. (2008)]. The mean (DWG) and mean total weight gain (TWG) values corresponded with the mean total feed intake (TFI) and mean daily feed intake (DFI) values since high feed intake of a well-balanced diet usually result in high growth rate as indicated by Sotolu and Byanyiko, (2010). Similarly,(Rita et al. (2009), Al-Ruqaie et al. (2011) and Adeyemo et al. (2013)) demonstrated that there were no significant differences $(\mathrm{p} \geq 0.05)$ for all treatments on average weight gain when broiler chicks were fed diets containing $0,25,50,75$ and $100 \%$ biscuit waste $(\mathrm{BW})$ respectively.

Table (2): Effect of replacing yellow corn with different dietary cake by-products (CBP) levels on live body weight, daily weight gain, daily feed consumption and feed conversion ratio of broilers.

\begin{tabular}{|c|c|c|c|c|c|c|c|c|}
\hline Item & $\begin{array}{c}100 \% \text { Corn } \\
0 \%(\mathrm{CBP}) \\
\mathrm{T}_{1} \\
\end{array}$ & $\begin{array}{c}85 \% \\
15 \% \\
\mathrm{~T}_{2} \\
\end{array}$ & $\begin{array}{c}70 \% \\
30 \% \\
\mathrm{~T}_{3} \\
\end{array}$ & $\begin{array}{c}55 \% \\
55 \% \\
\mathrm{~T}_{4} \\
\end{array}$ & $\begin{array}{c}40 \% \\
60 \% \\
\mathrm{~T}_{5} \\
\end{array}$ & $\begin{array}{c}25 \% \\
75 \% \\
\mathrm{~T}_{6} \\
\end{array}$ & $\begin{array}{c}0 \% \\
100 \% \\
\mathrm{~T}_{7} \\
\end{array}$ & Sig. \\
\hline \multicolumn{9}{|c|}{ Live body weight (LBW) (g): } \\
\hline 7 days & $\begin{array}{l}139.53 \\
\pm 6.95\end{array}$ & $\begin{array}{l}140.40 \\
\pm 6.19\end{array}$ & $\begin{array}{l}140.63 \\
\pm 5.86\end{array}$ & $\begin{array}{l}140.96 \\
\pm 5.54\end{array}$ & $\begin{array}{l}140.66 \\
\pm 4.48\end{array}$ & $\begin{array}{l}140.20 \\
\pm 3.86\end{array}$ & $\begin{array}{l}139.96 \\
\pm 3.74\end{array}$ & NS \\
\hline 40 days & $\begin{array}{l}1980.68 \\
\pm 34.33 \\
\end{array}$ & $\begin{array}{l}1970.54 \\
\pm 68.15\end{array}$ & $\begin{array}{r}2133.22 \\
\pm 54.83\end{array}$ & $\begin{array}{l}2019.50 \\
\pm 81.11 \\
\end{array}$ & $\begin{array}{l}1940.50 \\
\pm 37.35\end{array}$ & $\begin{array}{l}1900.54 \\
\pm 40.65\end{array}$ & $\begin{array}{l}1963.74 \\
\pm 21.05 \\
\end{array}$ & NS \\
\hline \multicolumn{9}{|c|}{ Daily weight gain (DWG) (g / day): } \\
\hline $\begin{array}{l}7-40 \\
\text { days }\end{array}$ & $\begin{array}{l}55.82 \\
\pm 0.97\end{array}$ & $\begin{array}{c}55.46 \\
\pm 1.68\end{array}$ & $\begin{array}{c}60.38 \\
\pm 1.35\end{array}$ & $\begin{array}{c}56.93 \\
\pm 2.06\end{array}$ & $\begin{array}{l}54.54 \\
\pm 1.01\end{array}$ & $\begin{array}{c}53.34 \\
\pm 0.96\end{array}$ & $\begin{array}{l}55.27 \\
\pm 0.58\end{array}$ & NS \\
\hline \multicolumn{9}{|c|}{ Daily feed consumption (DFC) (g/ day): } \\
\hline $\begin{array}{l}7-40 \\
\text { days }\end{array}$ & $\begin{array}{l}101.21 \\
\pm 2.82 \\
\end{array}$ & $\begin{array}{l}102.91 \\
\pm 1.84 \\
\end{array}$ & $\begin{array}{l}110.40 \\
\pm 2.17 \\
\end{array}$ & $\begin{array}{l}105.56 \\
\pm 5.35 \\
\end{array}$ & $\begin{array}{r}103.05 \\
\pm 5.66 \\
\end{array}$ & $\begin{array}{r}103.14 \\
\pm 3.50 \\
\end{array}$ & $\begin{array}{l}107.18 \\
\pm 1.90 \\
\end{array}$ & NS \\
\hline \multicolumn{9}{|c|}{ Feed conversion ratio (FCR): } \\
\hline $\begin{array}{l}\text { 7- } 40 \\
\text { days }\end{array}$ & $\begin{array}{c}1.82 \\
\pm 0.07\end{array}$ & $\begin{array}{c}1.86 \\
\pm 0.06\end{array}$ & $\begin{array}{c}1.83 \\
\pm 0.05\end{array}$ & $\begin{array}{c}1.86 \\
\pm 0.10\end{array}$ & $\begin{array}{c}1.89 \\
\pm 0.13\end{array}$ & $\begin{array}{c}1.93 \\
\pm 0.04\end{array}$ & $\begin{array}{c}1.94 \\
\pm 0.04\end{array}$ & NS \\
\hline $\begin{array}{l}\text { Mortality } \\
\text { numbers }\end{array}$ & 2 & 1 & 2 & 4 & 4 & 1 & 0 & \\
\hline
\end{tabular}

\section{Daily feed consumption (DFC) and feed conversion ratio (FCR):}

Results presented in Table (2) showed that no significant $(\mathrm{P}>0.05)$ differences between groups of birds fed different dietary treatments in DFC or FCR values at 7-40 days of age. However, data demonstrated that birds fed diet containing 30\% CBP had highest DFC value (110.40 g) and birds fed control diet had lowest DFC value (101.21 g) compared with other treatments. The highest numerical values for feed consumption recorded in treatments containing CBP compared to control group could be as a result of sweet nature and smell. These results are in agreement with those obtained by Al-Ruqaie et al. (2011), Torki and Kimiaee (2011) and Ajasin et al. (2010) they reported that the substitutions of dietary corn from $0 \%$ up to $100 \%$ with Biscuit waste byproduct (BWP) no adverse effect on feed intake FT or FCR.

\section{Mortality rate:}

Conditions of the present study were kept firmly under control which made all birds appear healthy and vigorous. Mortality numbers were recorded 2, 1, 2, 4, 4, 1 and 0 , respectively between treatments from T1 to T7 indicating that mortality numbers did not show any significant differences between the experimental treatments and the control one. The results are in agreement with other studies where bakery wastes did not show any 
significant difference on mortality in broilers [Madiya et al. (2003), Al-Tulaihan et al. (2004), Ragab et al. (2006), Najafabadi et al. (2007), Omole et al. (2013) and Ironkwe et al. (2015)].

\section{Carcass characteristics:}

As shown in Table (3) no significant $(\mathrm{P}>0.05)$ differences were observed in percentages of carcass between all treatments. Numerically, the birds fed diet containing 45\% CBP followed by diet containing 30\% CBP had the highest percentages of carcass $(71.95 \%$ and $71.73 \%$, respectively) while, birds fed diet containing $30 \%$ CBP followed by birds fed diet containing $45 \%$ CBP had the highest percentages of total edible parts $(76.30 \%$ and $75.70 \%$, respectively) compared with other treatments and birds fed diets containing 75\% CBP had lowest percentages of carcass and total edible parts (66.65 and $70.93 \%$, respectively).

Table (3): Effect of replacing yellow corn with different dietary cake by-products (CBP) levels on carcass characteristics at $\mathbf{4 0}$ days of age.

\begin{tabular}{|c|c|c|c|c|c|c|c|c|}
\hline Item $\%$ & $\begin{array}{c}100 \% \text { Corn } \\
0 \% \text { (CBP) } \\
\mathrm{T}_{1} \\
\end{array}$ & $\begin{array}{c}85 \% \\
15 \% \\
\mathrm{~T}_{2} \\
\end{array}$ & $\begin{array}{c}70 \% \\
30 \% \\
\mathrm{~T}_{3} \\
\end{array}$ & $\begin{array}{c}55 \% \\
55 \% \\
\mathrm{~T}_{4} \\
\end{array}$ & $\begin{array}{c}40 \% \\
60 \% \\
\mathrm{~T}_{5} \\
\end{array}$ & $\begin{array}{c}25 \% \\
75 \% \\
\mathrm{~T}_{6} \\
\end{array}$ & $\begin{array}{c}0 \% \\
100 \% \\
\mathrm{~T}_{7} \\
\end{array}$ & Sig. \\
\hline Caracas & $\begin{array}{r}68.84 \\
\pm 0.72\end{array}$ & $\begin{array}{l}69.62 \\
\pm 0.63\end{array}$ & $\begin{array}{l}71.73 \\
\pm 2.08\end{array}$ & $\begin{array}{l}71.95 \\
\pm 0.77\end{array}$ & $\begin{array}{l}69.45 \\
\pm 0.53\end{array}$ & $\begin{array}{l}66.65 \\
\pm 1.92\end{array}$ & $\begin{array}{c}69.72 \\
\pm 1.98\end{array}$ & NS \\
\hline EP & $\begin{array}{l}72.91 \\
\pm 0.65\end{array}$ & $\begin{array}{r}74.49 \\
\pm 0.72\end{array}$ & $\begin{array}{r}76.30 \\
\pm 1.87\end{array}$ & $\begin{array}{l}75.70 \\
\pm 0.77\end{array}$ & $\begin{array}{l}73.41 \\
\pm 0.31\end{array}$ & $\begin{array}{l}70.93 \\
\pm 2.25\end{array}$ & $\begin{array}{l}73.67 \\
\pm 2.07\end{array}$ & NS \\
\hline Giblets & $\begin{array}{c}4.07 \\
\pm 0.27\end{array}$ & $\begin{array}{c}4.78 \\
\pm 0.51\end{array}$ & $\begin{array}{c}4.57 \\
\pm 0.22\end{array}$ & $\begin{array}{c}3.75 \\
\pm 0.14\end{array}$ & $\begin{array}{c}3.96 \\
\pm 0.23\end{array}$ & $\begin{array}{c}4.27 \\
\pm 0.35\end{array}$ & $\begin{array}{c}3.95 \\
\pm 0.14\end{array}$ & NS \\
\hline Liver & $\begin{array}{c}1.99 \\
\pm 0.09\end{array}$ & $\begin{array}{c}2.63 \\
\pm 0.35\end{array}$ & $\begin{array}{c}2.33 \\
\pm 0.54\end{array}$ & $\begin{array}{c}1.81 \\
\pm 0.06\end{array}$ & $\begin{array}{c}2.25 \\
\pm 0.17\end{array}$ & $\begin{array}{c}2.41 \\
\pm 0.32\end{array}$ & $\begin{array}{c}1.97 \\
\pm 0.31\end{array}$ & NS \\
\hline Heart & $\begin{array}{c}0.52 \\
\pm 0.05\end{array}$ & $\begin{array}{c}0.61 \\
\pm 0.09\end{array}$ & $\begin{array}{c}0.50 \\
\pm 0.02\end{array}$ & $\begin{array}{c}0.60 \\
\pm 0.05\end{array}$ & $\begin{array}{c}0.49 \\
\pm 0.04\end{array}$ & $\begin{array}{c}0.46 \\
\pm 0.06\end{array}$ & $\begin{array}{c}0.47 \\
\pm 0.04\end{array}$ & NS \\
\hline Gizzard & $\begin{array}{c}1.41 \\
\pm 0.19\end{array}$ & $\begin{array}{c}1.44 \\
\pm 0.16\end{array}$ & $\begin{array}{c}1.62 \\
\pm 0.13\end{array}$ & $\begin{array}{c}1.25 \\
\pm 0.11\end{array}$ & $\begin{array}{c}1.09 \\
\pm 0.09\end{array}$ & $\begin{array}{c}1.26 \\
\pm 0.13\end{array}$ & $\begin{array}{c}1.37 \\
\pm 0.19\end{array}$ & NS \\
\hline Bursa & $\begin{array}{c}0.11 \\
\pm 0.01\end{array}$ & $\begin{array}{c}0.14 \\
\pm 0.02\end{array}$ & $\begin{array}{c}0.14 \\
\pm 0.01\end{array}$ & $\begin{array}{c}0.13 \\
\pm 0.01\end{array}$ & $\begin{array}{c}0.14 \\
\pm 0.02\end{array}$ & $\begin{array}{c}0.11 \\
\pm 0.01\end{array}$ & $\begin{array}{c}0.14 \\
\pm 0.01\end{array}$ & NS \\
\hline Spleen & $\begin{array}{c}0.14 \\
\pm 0.01 \\
\end{array}$ & $\begin{array}{c}0.12 \\
\pm 0.01 \\
\end{array}$ & $\begin{array}{c}0.12 \\
\pm 0.01 \\
\end{array}$ & $\begin{array}{c}0.11 \\
\pm 0.01\end{array}$ & $\begin{array}{c}0.12 \\
\pm 0.01 \\
\end{array}$ & $\begin{array}{c}0.13 \\
\pm 0.01 \\
\end{array}$ & $\begin{array}{c}0.12 \\
\pm 0.01 \\
\end{array}$ & NS \\
\hline
\end{tabular}

$a, b$ Means within the same row with different superscripts are significantly different, Sig. $=$ Significance, $N S=N o t$ significant.; $E P=$ Carcass + Giblets; Giblets $=($ Liver + Gizzard + Heart $)$.

\section{Economic evaluation:}

Table (4) represents economic efficiency of Hubbard broiler chicks fed different experiment diets for 40 days of age.

Table (4): Effect of replacing yellow corn with different dietary cake by-products (CBP) levels on economic efficiency.

\begin{tabular}{lccccccc}
\hline & $100 \%$ Corn & $85 \%$ & $70 \%$ & $55 \%$ & $40 \%$ & $25 \%$ & $0 \%$ \\
Item\% & $0 \%$ (CBP) & $15 \%$ & $30 \%$ & $55 \%$ & $60 \%$ & $75 \%$ & $100 \%$ \\
& $\mathrm{~T}_{1}$ & $\mathrm{~T}_{2}$ & $\mathrm{~T}_{3}$ & $\mathrm{~T}_{4}$ & $\mathrm{~T}_{5}$ & $\mathrm{~T}_{6}$ & $\mathrm{~T}_{7}$ \\
\hline Price feed/ $\mathrm{Kg}^{1}$ (L.E.) & 6.99 & 6.80 & 6.64 & 6.47 & 6.30 & 6.10 & 5.79 \\
Total feed cost (L.E.) $^{2}$ & 21.59 & 21.86 & 22.85 & 21.89 & 20.73 & 20.67 & 19.45 \\
Total costs $^{2}$ & 38.59 & 38.86 & 39.85 & 38.89 & 37.73 & 37.67 & 36.45 \\
Total revenus $^{3}$ & 51.58 & 51.24 & 55.78 & 52.58 & 50.37 & 49.28 & 51.04 \\
Net revenus $^{4}$ & 29.99 & 29.38 & 32.93 & 30.69 & 29.64 & 28.61 & 31.60 \\
Economic efficiency $^{5}$ & 77.70 & 75.59 & 82.64 & 78.91 & 78.57 & 75.93 & 86.68 \\
(E.E.) $_{\text {Relative efficiency }}{ }^{6}$ & 100 & 97.28 & 106.35 & 101.56 & 101.11 & 97.72 & 111.56 \\
Price feed/Kg & & & & & \\
P.E.) & 6.99 & 6.80 & 6.64 & 6.47 & 6.30 & 6.10 & 5.79 \\
\hline
\end{tabular}

${ }^{7}$ based on average price of diets during the experimental all time; ${ }^{2}$ Total costs $=$ Total feed cost (L.E.) + Fixed cost (17 L.E.), while Fixed cost (price of labors, medication and electricity...etc., ${ }^{3}$ According to the local price of Kg $L B W$ which was 28.00 L.E.; ${ }^{4}$ Net revenues per unit feed cost; . ${ }^{5}$ Net revenue/ total cost* $100 ;{ }^{6}$ R.E. (treatment)/ E.E. (control)*100. 
Results showed that, the birds fed on diets containing CBP at levels of 30, 45, 60 and 100\% had higher values of the relative efficiency percentage $(106.35,101.56,101.11$ and 111.56 ; respectively) compared the control. While, T2 (15\% CBP) and T6 (75\% CBP) had the lowest ones $(97.28 \%)$ and $(97.72 \%)$. This result is similar to those observed by Madiya et al. (2003); Al-Ruqaie et al. (2011) and Adeyemo et al. (2013) in their feeding trials with broiler chicks in which they fed diets containing varying levels of CBP as a replacement for maize. The absolute values clearly show that feed cost per $\mathrm{kg}$ live weight gain decreased with increasing levels of CBP, similar to the trend observed for the cost of the various diets. The decline in the feed cost as the amount of maize in the diet was reduced by replacement with CBP was mainly due to the huge price disparity between maize (LE $4.73 / \mathrm{kg})$ and the CBP (LE $3.0 / \mathrm{kg})$.

\section{CONCLUSION}

It could be concluded that CBP; can be used as a 100\% substitute for yellow corn in the rations of Hubbard chicks without negative effects on the productive performance and carcass characteristics, while achieving the best economic return.

\section{REFERENCES}

Adeyemo, G.O., O.R. Oni and O.G. Longe (2013). Effect of dietary biscuit waste on performance and carcass characteristics of broilers. Food Science and Quality Management, (12): 1-10.

Afzalzadeh, A., A. Boorboor, D. Ghandi; H. Fazaeli and N. Kashan (2007). Effect of feeding bakery waste on sheep performance and the carcass fat quality. J. Anim. Vet. Adv., (6): 559-562.

Ajasin, F.O., A.J. Omole, J.B. Fapounda and O.O. Obi (2010). The feeding value of biscuit waste as replacement for maize in the diet of growing snails. Journal of American science, 6(2): 1-5.

Al-Ruqaie, I.M., S.A. Swillam, H.A. Al-Batshan and T.M. Shafey (2011). Performance, Nutrient Utilization and Carcass Characteristics and Economic Impact of Broiler Chickens Fed Extruded Bakery Waste. Journal of Animal and Veterinary Advances, 10 (16): 2061-2066.

Al-Tulaihan, A.A., H. Najib and S.M. Al-Eid (2004). The Nutritional Evaluation of Locally Produced Dried Bakery Waste (DBW) in the Broiler Diets. Pakistan Journal of Nutrition, 3 (5): 294-299.

AOAC (2012). Official Methods of Analysis. 19th ed. Gaithersburg,, MD: AOAC International.

Ayanrinde, O.J., A.O. Owosibo and A.A. Adeyemo (2014). Performance Characteristics of Broilers Fed Bread Waste Based Diets. International Journal of Modern Plant \& Animal Sciences, 2(1): 1-11.

Cowieson, A.J. (2005). Factors that affect the nutritional value of maize for broilers. Animal Feed Science Technology, 119: 293-305

Duncan, D.B. (1955). Multiple range and Multiple F tests. Biometrics, 11:142.

El-Yamny A.T., S.A. Abd El-Latif and A.A. El-Ghamry (2003). Effect of using some untraditional energy sources in growing Japanese quail diet on performance, digestibility, metabolic changes and economic efficiency. Egypt. Poult. Sci., 23: 787-806.

Gonzalez-Alvardo, J.M., E. Jimenez-Marano, D.G. Valencia, R. Lazaro and G.G. Mateos (2008). Effect of fibre source and heat processing of the cereal on development and $\mathrm{PH}$ of the gastrointestinal tract of broilers fed diets based on corn or rice. Poultry Science, 87: 1779-1795

Ironkwe, M.O., B.M. Esonu and L.A.F. Akinola (2015). Performance Characteristics and Carcass Yield of Indigenous Turkeys Fed Indomie Waste-Based Diets. Journal of Agriculture and Veterinary Science, (8): 8891.

Madiya, A.T., C.M.E. McCrindle, C.M. Veary and S.P.R. Bisschop (2003). The use of dried bakery products in a free-choice feeding method for small-scale broiler production. Journal of the South African Veterinary Association, 74(4): 111-116.

Mousa, E.I., Al-Mohizea, I.S. and M.A. A1-Kanha (1992). Chemical composition and nutritive value of various breads in Saudi Arabia. Food Chemistry, 43: 259-264. 
Najafabadi, R.J., J. Pourreza, A.H. Samie and M.A. Edriss (2007). The influence of enzyme supplementation on wheat and inedible pasta utilization in broiler diets. $16^{\text {th }}$ European Symposium on Poultry Nutrition.

NRC; National Research Council (1994). Nutrient Requirements of Poultry. $9^{\text {th }}$ revised Ed. National Academy press, Washington, DC., USA.

Omole, A.J., C.N. Okpeze, R.A. Salako, O.O. Obi and J.O. Fayenuwo (2013). Utilization of noodle waste as replacement for Maize in the diet of broiler starter chickens. American Journal of Experimental Agriculture, 3(4): 1012-1019.

Ragab, M.S., M.M. Namra and A.M.R. Osman (2006). Effect of replacing yellow corn by bakery by-product on Broiler performance. Egypt. Poult. Sci.,(26) (II): 513-534.

Rita, N., B.S.M. Ronald, S. Baegan and A. Bharathidasan (2009). Biscuit powder as an unconventional feed in piglets. Indian J. Anim. Res., 43 (3): 215-216.

SAS (2005). User's Guide, Version 9. SAS Institute, Cary, NC.

Sotolu, A.O. and S.Y. Byanyiko (2010). Nutritive potentials of Parkia biglobosa pulp meal in partial replacement for maize in the diets of African catfish (Clarias gariepimes) juvenile. Electronic Journal of Environmental, Agricultural \& Food Chemistry, 9(7): 1196-1202.

Torki, M. and V. Kimiaee (2011). Effects of Dietary Replacing Corn with Bakery by-product with or without Enzyme Supplementation on Performance of Laying Hens. 2nd International Conference on Environmental Science and Technology, IPCBEE vol.6 (2011).

Williams, P.E.V., P.A. Geraert, G. Uzu and G. Annison (1997). Factors affecting non -starch polysaccharide digestibility in poultry. In : Morand-Fehr P. (ed.). Feed manufacturing in Southern Europe: New challenges. Zaragoza : CIHEAM, 125-134.

Zand, N. and F. Foroudi (2011). Effect of feeding different levels of corn snack waste on broiler performance. African Journal of Biotechnology,10(7): 1260-1264.

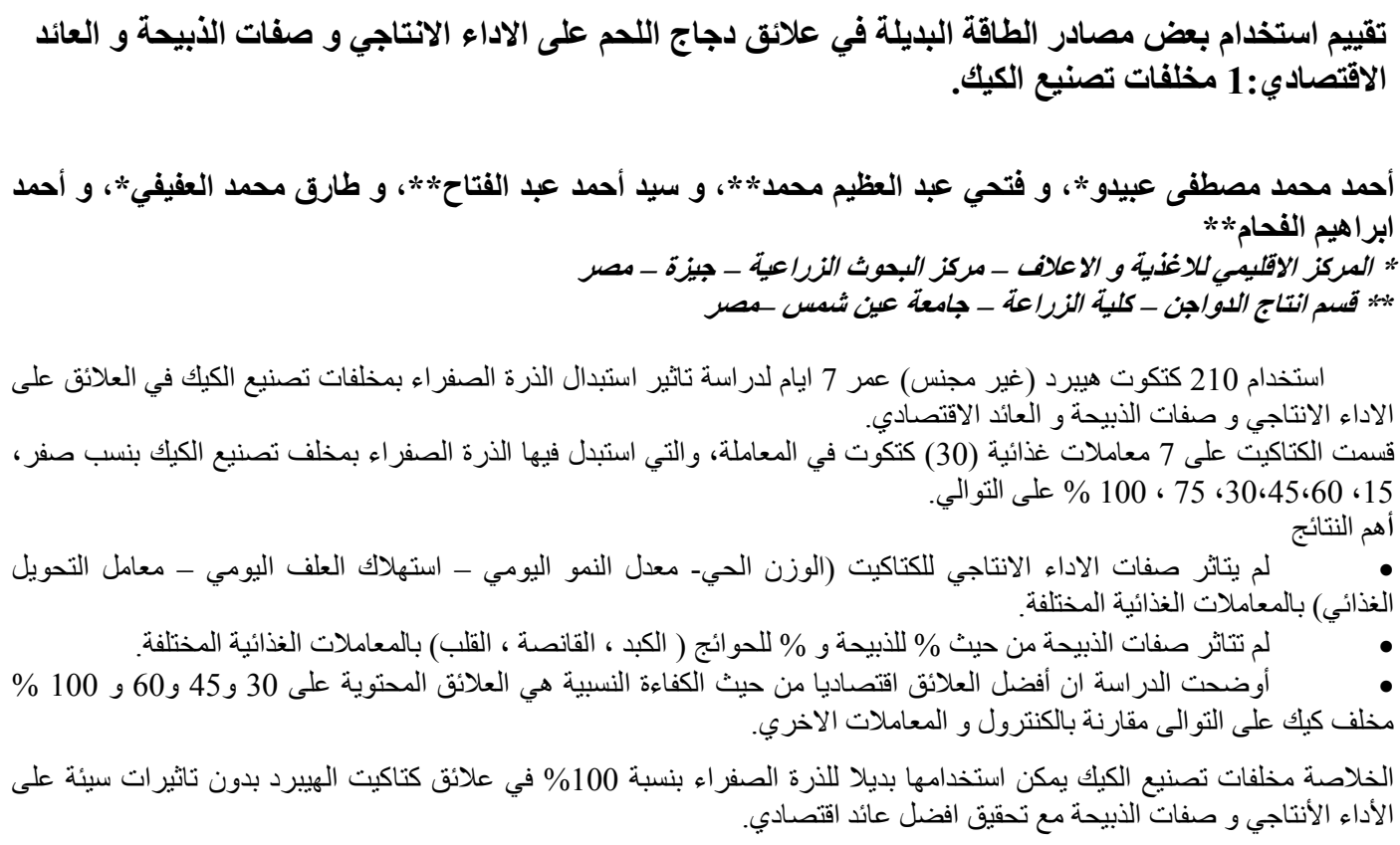

